UDC 330.43:514.1:51-77

JEL Classification: C01, C02, G32, O32, P40

http://doi.org/10.21272/mmi.2018.4-20

Pavlo Berzin,

D.Sc., Professor, Taras Shevchenko National University, Ukraine

Olena Shyshkina,

Ph.D., Associate Professor, Chernihiv National University of Technology, Ukraine

Olha Kuzmenko,

D.Sc., Associate Professor, Sumy State University, Ukraine

Hanna Yarovenko,

Ph.D., Associate Professor, Sumy State University, Ukraine

\title{
INNOVATIONS IN THE RISK MANAGEMENT OF THE BUSINESS ACTIVITY OF ECONOMIC AGENTS
}

\begin{abstract}
The article is devoted to the development of an innovative approach in the risk management of the business activity of economic agents, which is based on the application of economic and mathematical methods. The approach provides the implementation of the following phases. At the first stage, the formation of four groups of the main risk-generating factors of the business activity in the internal and external environments is proposed, taking into account the stimulant and disinfectant factors, their intensive and extensive nature of the impact. At the second stage, the study of the selected factors for abnormal emissions is conducted. For this purpose, the factors are given in the form of time series, which are checked for anomalies with the modified Irwin criterion. The third stage defines the procedure for selecting relevant factors for each of the four groups that determine the risk of business activity. The authors propose to conduct a regression analysis, in which the standardized regression equations are constructed to assess the importance of the factors and their impact on the risk of the business activity. The fourth stage of the innovative approach is devoted to the development of integrated indicators of risk groups based on the Minkowski Metric. The value of the integral indicator, which is approaching 1, will indicate that there is no risk, otherwise, the factors generate excessive risk. At the fitth stage, a risk business model based on four components and a quadrangle centroid are built. The standard model was built using the software package "GeoGebra Classical". As a result, a square whose centre of mass lies at the intersection of its diagonals, which also coincides with the centre of the described circle is obtained. At the sixth stage, an analysis of the results of simulation and the definition of strategies is carried out. The authors proposed to construct a scenario of probable variants of relations between the four groups of risk factors, which includes possible directions for improving the components of one or another group of risks. The construction of such scenarios will increase the efficiency of management decisions since it allows you to gradually track the impact of changes in risk and get the predicted result.
\end{abstract}

Keywords: business activity, the risk of the business activity, economic agent, risk management, innovative approach, risk-generating factor, graphics model, the centre of mass.

Introduction. The effectiveness of the functioning and development of economic entities in the market economy is largely ensured by the geography of business relations, the efforts made by the company to enter the product markets, the presence of constant ties with contractors, the formation of human resources, the activity of innovation and investment, business reputation, i.e. it depends on the business activity. The main objectives of the management of economic agents are to increase the efficiency of their development, to implement their tactical and strategic goals, which is largely dependent on the timely identification, assessment and neutralization of risks that can cause loss both in profit/income and in capital, and not only reflected in the parameters of the business activity, but also affect the level of profitability, competitiveness and investment attractiveness of such entities in general. Therefore, there is a need for innovative tools, which will timely identify the factors that affect the increase of risk and

Cite as: Berzin, P., Shyshkina, O., Kuzmenko, O., \& Yarovenko, H. (2018). Innovations in the Risk Management of the Business Activity of Economic Agents. Marketing and Management of Innovations, 4, 221-233. http://doi.org/10.21272/mmi.2018.4-20 
P. Berzin, O. Shyshkina, O. Kuzmenko, H. Yarovenko. Innovations in the Risk Management of the Business Activity of Economic Agents

deterioration of the business activity, predict the future state of the economic agent and prevent emergencies in the future. The economic-mathematical modelling is one of such tools, the application of which will contribute to the timely assessment of the impact of factors on risk and the identification of negative trends. In this regard, the relevance and timeliness of issues devoted to the development of an innovative approach in the risk management of the business activity, which is considered in this research work, do not raise any objections.

Literature Review. Questions concerning the study of the essence, the content of the business activity, parameters of its evaluation and analysis criteria were reflected in the works of such researchers as: Anisimova O. M. [1], Harasyuk O. A. [2], Kashchena N. B. [3], Zaikina O. O. [4], Kireytsev H. H. [5], Kovalenko L. O. [6], Kurylenko T. P. [7], Myeshkova N. L. [8], Mets V. O. [9], Petrenko M. I. [10], Tkachuk H. Y. [11], Turylo A. M. [12], Tsal-Tsalko Y. S. [13] Sheremet A. D. [14], Yakovenko T. V. [15] and other scholars. These works outline the general theoretical approaches that form the scientific basis for the further applied research on problematic issues of the business activity.

The problem of risk management of economic agents of various industries in modern economic conditions is in the sight of numerous foreign and domestic scientists, such as: Blank I. A [16], Vitlins'kyy V. V. [17], Hrabovoyi P. H. [18], Hranaturov V. M. [19], Kleyner H. B. [20], Popova A. Y. [21], Rohov M. A. [22], Redkhed K. [23], Hius S. [23], Savchuk V.P. [24], Starostyna A. O. [25], Shapkyn A. S. [26], Lobanov A. A. [27], Chuhunov A. V. [27] et al. In the presented works, the approaches to identification and risk assessment, which are based on the use of various quantitative and qualitative methods, are considered.

The qualitative assessment of the business activity risks consists in analyzing the sensitivity of financial results to changes in the basic parameters of activity in conditions of uncertainty and instability of the market situation and allows to determine the deviation of the actual data from the planned ones. Such widespread qualitative methods as: expert, decision trees, interest rates, scenarios, the concept of Value at Risk, are considered in the works of Hrabovoyi P. H. [18], Hranaturov V. M. [19], Redkhed K. [23], Hius S. [23], Shapkyn A. S. [26], Lobanov A. A [27], Chuhunov A. V. [27], Shyshkina O. [28]. Since the activities of the economic agents occur under conditions of uncertainty of the environment, the most popular identification methods for researchers are expert ones: the method of "brainstorming", the method of Crawford Cards, the method of the nominal group, the method of checklists, the Delphi method - which were proposed in [18, 19, 23, 26, 29].

The quantitative assessment determines the probability of occurrence of the business activity risks and the impact of the consequences of risks on the operation and development of an industrial enterprise, which helps top management to improve the implementation of tactical and strategic decisions. Thus, in the process of quantitative assessment, economic-statistical and analogue methods of evaluation are used, which were considered in scientific works [18, 19, 23, 26, 27, 28].

In general, the scientific achievements of scientists on risk issues are significant. The use of quantitative and qualitative methods for assessing the risks of the business activity has its advantages and disadvantages and is limited to the experience of its user by financial and risk managers of companies, the inability to take into account all factors of risk and other factors. However, despite a large number of publications on identified problems, the issue of identifying and assessing the risks of the business activity of economic agents remains insufficiently investigated, requiring the further elaboration and application of modern and powerful innovative methods that determine the purpose of this scientific work.

The purpose of the article is to develop an innovative approach to assessing the risks of the business activity of economic agents, as one of the effective management tools based on the application of mathematical methods.

Research results. The study of the interpretations of the business activity allows suggesting that in terms of its economic content, it can be viewed both in the narrow sense and in the broad sense. In the 
P. Berzin, O. Shyshkina, O. Kuzmenko, H. Yarovenko. Innovations in the Risk Management of the Business Activity of Economic Agents

narrow sense - the business activity is considered in the context of production and commercial activities of economic agents, is identified with the effectiveness of the efforts, the optimal use of resources, and the effectiveness of management. That is, the narrow aspect of this concept is based on the analysis and evaluation of the components of the internal environment and takes into account the impact of management on the efficiency of the functioning and development of the economic agent. In the broad sense, the business activity is embodied in the full spectrum of efforts aimed at promoting an economic agent in the markets of products (goods, works, services), labour, and capital. Thus, the broad aspect more fully reflects its connection with the external environment. To summarize the above, we note that the notion of the business activity is a broad phenomenon and covers practically all aspects of the work of any economic agent operating in conditions of risk and uncertainty of the environment. Therefore, an innovative approach to risk management of the business activity of economic agents, developed on the basis of $[30,31]$, was proposed in this article in order to reduce the probability of occurrence of risk situations that could lead to negative consequences and decrease the general level of the business activity. The approach presupposes the implementation of the following stages.

At the first stage, we choose the basis of indicators-factors that affect the risk of the business activity. In our opinion, the business activity is a complex category integrated in a set of balanced indicators that embodies the multifaceted activity of the economic agent and contains the entire spectrum of efforts aimed at effective functioning and development, embodied in the positive image of the economic agent, the investment attractiveness, optimal use of available resources, constant increase of production, economic, personnel, financial and other types of potential in the short, medium and long-term. When choosing the factors generating risk, one must take into account: the business activity of economic agents in the internal environment and the activity in the external environment.

Also, one group of factors has a positive effect, resulting in a reduction in risk. Such factors are stimulants. Another group of indicators has a negative impact on risk, leading to its increase, respectively, they are called disinfectants.

Regardless of the environment in which the economic agent operates, and under the influence of which the factors of impact on the risk of the business activity are formed, it is important to take into account how these factors influence. That is, it is necessary to take into account the intensive and extensive impact. As a rule, intensive factors express qualitative signs and extensive - quantitative certainty of the business activity.

Based on our assumptions, we will form a table of factors that affect the risk of the business activity, taking into account the environment, the nature of the impact, as well as the sign of this impact (Tables 1-2).

Table 1 - Internal risk-forming factors of the business activity and probable risks that match them

\begin{tabular}{|l|c|l|}
\hline \multicolumn{1}{|c|}{ Risk-forming factors } & $\begin{array}{c}\text { Nature of } \\
\text { impact }\end{array}$ & \multicolumn{1}{c|}{ Business activity risks } \\
\hline \multicolumn{1}{|c|}{1} & 2 & \multicolumn{1}{c|}{3} \\
\hline $\begin{array}{l}\text { Quality of production and financial } \\
\text { management: } \\
\text { leadership qualification (+); } \\
\text { employees qualification (+) }\end{array}$ & & $\begin{array}{l}\text { - qualification risk; - risk associated with staff turnover; - risk of } \\
\text { conflict of interests of owners, administration and employees of } \\
\text { the enterprise }\end{array}$ \\
\cline { 1 - 2 } $\begin{array}{l}\text { Control over product quality and } \\
\text { timeliness of its deliveries (+) }\end{array}$ & Intensive & $\begin{array}{l}\text { - risk of rejection of the quality of the delivered product from the } \\
\text { established standard/standard/technical specification, etc.; - } \\
\text { risks of untimely delivery of products; - transport and customs } \\
\text { risks }\end{array}$ \\
\hline
\end{tabular}


P. Berzin, O. Shyshkina, O. Kuzmenko, H. Yarovenko. Innovations in the Risk Management of the Business Activity of Economic Agents

Table 1

\begin{tabular}{|c|c|c|}
\hline 1 & 2 & 3 \\
\hline $\begin{array}{l}\text { Assortment policy, expansion of } \\
\text { the product range }(+)\end{array}$ & \multirow{5}{*}{ Intensive } & $\begin{array}{l}\text { - commodity risk; - risk of banning the advertisement of } \\
\text { individual product groups; - consumer risk; - manufacturer's risk; } \\
\text { - price risk; - inflationary risk; - currency risk }\end{array}$ \\
\hline Advertising policy (+) & & $\begin{array}{l}\text { - risk of banning the advertisement of individual product groups; } \\
\text { - consumer risk; - price risk }\end{array}$ \\
\hline Investment attractiveness (+) & & $\begin{array}{l}\text { - investment risks (including the risk of real investment and the } \\
\text { risk of financial investment) }\end{array}$ \\
\hline $\begin{array}{l}\text { Insufficient flexibility of innovation } \\
\text { policy, level of implementation of } \\
\text { new technologies (+) }\end{array}$ & & $\begin{array}{l}\text { - innovative risks (the risk associated with the introduction of } \\
\text { new technologies, the use of new financial instruments, the } \\
\text { implementation of innovation projects, etc.) }\end{array}$ \\
\hline $\begin{array}{l}\text { Provision of assets: } \\
\text { profit level }(+) \text {; } \\
\text { revenue from product sale }(+) \text {; } \\
\text { amount of working capital }(+)\end{array}$ & & $\begin{array}{l}\text { - risk of financial sustainability (risk of imbalance in financial } \\
\text { development); - insolvency risk; - risk of unbalanced illiquidity }\end{array}$ \\
\hline $\begin{array}{l}\text { Effectiveness of production: } \\
\text { the volume of manufactured } \\
\text { products }(+) \text {; } \\
\text { cost of raw materials }(-)\end{array}$ & \multirow{5}{*}{ Extensive } & $\begin{array}{l}\text { - price risk; - risk of lowering the quality of products; - consumer } \\
\text { risk; - risk of changing the market share }\end{array}$ \\
\hline Debt level (-) & & $\begin{array}{l}\text { - loan risk (risk of non-repayment of a loan, risk of late payment } \\
\text { of a loan, risk of insufficient security of a loan); - interest rate risk } \\
\text { (risk of unexpected changes in interest rates on the financial } \\
\text { market) }\end{array}$ \\
\hline $\begin{array}{l}\text { Capital structure: } \\
\text { amount of equity capital }(+) \text {; } \\
\text { amount of borrowed capital }(-)\end{array}$ & & $\begin{array}{l}\text { - risk of financial sustainability (risk of imbalance in financial } \\
\text { development); - risk of insolvency; - the risk of unbalanced } \\
\text { liquidity }\end{array}$ \\
\hline Productivity $(+)$ & & $\begin{array}{l}\text { - risk of instability; - risk of uncertainty in the future; - risk of } \\
\text { resistance to changes and innovations from the employees of } \\
\text { the enterprise; - the risk associated with low material } \\
\text { remuneration for the results of work }\end{array}$ \\
\hline Cost of purchased shares (+) & & $\begin{array}{l}\text { - investment risks; - risks of financial inability to implement } \\
\text { innovations; - interest rate risks; - currency risks; - risks of } \\
\text { lowering the cost of capital }\end{array}$ \\
\hline
\end{tabular}

(+) - factor-stimulant: the increase in its value reduces the risk level; (-) - factor-disinfectant: the increase in its value multiplies the risk level

Sources: developed by the authors on the basis of [32]

Thus, to assess the risk, we choose 4 groups that form: 1) internal intensive factors; 2) internal extensive factors; 3 ) external intensive factors; 4) external extensive factors. At the second stage, the study of the selected factors (see Table 1-2) for anomalies is carried out. For this, the factors are given in the form of time series, that is, in the form of data rows that change over the selected time period. Such a situation is possible when the value of a row is significantly deviating from the average value, then, in this case, we are dealing with an abnormal value or an ejection. They also need to be taken into account in the modelling of economic phenomena, since abnormalities may not be a typical phenomenon that one should be able to detect and predict in future. Different criteria such as Irwin criterion modified Irwin criterion, Dixon criterion and others are used to study abnormal phenomena. For application in the developed innovation approach, we choose the modified Irwin criterion as the most simple and effective criterion based on comparing neighbouring levels of the row. 
P. Berzin, O. Shyshkina, O. Kuzmenko, H. Yarovenko. Innovations in the Risk Management of the Business Activity of Economic Agents

Table 2 - External risk-forming factors of the business activity and probable risks that match them

\begin{tabular}{|c|c|c|}
\hline Risk-forming factors & $\begin{array}{l}\text { Nature of } \\
\text { impact }\end{array}$ & Business activity risks \\
\hline Social activity $(+)$ & \multirow{7}{*}{ Intensive } & $\begin{array}{l}\text { - risks of increasing the social tension; - risks of reducing the } \\
\text { purchasing power }\end{array}$ \\
\hline Image of an economic agent $(+)$ & & $\begin{array}{l}\text { - risks of partners' selection and their reliability; - risks caused } \\
\text { by the inability to assess the qualitative composition of the } \\
\text { participants in credit relations; - risks associated with force } \\
\text { majeure }\end{array}$ \\
\hline Level of environmental activity (+) & & $\begin{array}{l}\text { - risk of reducing the sales markets; - risk of increased } \\
\text { penalties }\end{array}$ \\
\hline Products' standardization terms (+) & & $\begin{array}{l}\text { - risk of losing the market share; - risk of image loss; - risk of } \\
\text { reducing the competitiveness }\end{array}$ \\
\hline Political situation in the country $(+)$ & & $\begin{array}{l}\text { - risk of losing the international image; - risk of bankruptcy; - } \\
\text { risk of rising the social tension }\end{array}$ \\
\hline Competitiveness level (+) & & - risk of reducing the sales markets; - risk of losing the profit \\
\hline Tax burden $(-)$ & & $\begin{array}{l}\text { - risk of reducing the sales markets; - risk of increasing costs } \\
\text { for products (works, services); - price risks; - risk of increased } \\
\text { penalties }\end{array}$ \\
\hline $\begin{array}{l}\text { Change in the share of the } \\
\text { economic agent in the market of } \\
\text { products (works, services) }(+)\end{array}$ & \multirow{5}{*}{ Extensive } & - price risks; - commodity risks; - assortment risks \\
\hline $\begin{array}{l}\text { Fluctuations in the volume of foreign } \\
\text { trade turnover }(+)\end{array}$ & & $\begin{array}{l}\text { - political and legal risks; - risks of business reputation of the } \\
\text { country, an agent in the world market; - risks caused by the } \\
\text { restrictions on cooperation and trading and other activities; - } \\
\text { currency risks }\end{array}$ \\
\hline $\begin{array}{l}\text { Change in the number of } \\
\text { workplaces }(+)\end{array}$ & & $\begin{array}{l}\text { - demographic risks; - risks of untimely reduction of personnel } \\
\text { in the context of hidden unemployment; - risks of lack of } \\
\text { employees of relevant qualities; - risk of rising the social } \\
\text { tensions in society; - risk of declining the qualifications of } \\
\text { temporarily unemployed }\end{array}$ \\
\hline Profit from stock activity $(+)$ & & $\begin{array}{l}\text { - investment risks; - risks of financial inability to implement } \\
\text { innovations; - interest rate risks; - currency risks; - risks of } \\
\text { lowering the cost of capital }\end{array}$ \\
\hline $\begin{array}{l}\text { Inflation rate }(-) \\
\text { Price level }(-) \\
\text { Purchasing power of the } \\
\text { population }(+) \\
\text { Average salary }(+)\end{array}$ & & $\begin{array}{l}\text { - risks of unemployment; - price risks and commodity risks; - } \\
\text { risks of reducing the purchasing power and reorienting the } \\
\text { population to essential goods; - risk of rising the social } \\
\text { tensions in society }\end{array}$ \\
\hline
\end{tabular}

(+) - factor-stimulant: the increase in its value reduces the risk level; (-) - factor-disinfectant: the increase in its value multiplies the risk level

Sources: developed by the authors on the basis of [32]

First, an average square deviation in time series is calculated, though not all set of observations but only three observations are taken (Formula 1):

$$
\hat{\sigma}_{y}=\sqrt{\frac{\sum_{t=1}^{n}\left(\left(y_{t-1}-\bar{y}_{t}\right)^{2}+\left(y_{t+1}-\bar{y}_{t}\right)^{2}\right)}{2}}
$$


P. Berzin, O. Shyshkina, O. Kuzmenko, H. Yarovenko. Innovations in the Risk Management of the Business Activity of Economic Agents

where $\hat{\sigma}_{y}$ - average square deviation for three observations; $\mathrm{yt}-1$ - previous level of the row; $\mathrm{y}_{\mathrm{t}+1}-\mathrm{next}$ level of the row; $n$ - the length of the row, which in this case will be equal to $3 ; \bar{y}_{t}$ - average value for two neighbouring values, which is calculated as:

$$
\bar{y}_{t}=\frac{y_{t-1}+y_{t+1}}{2}, t=2,3, \ldots, n-1
$$

To find abnormal values of the low levels, the characteristics of it (Formula 3) are calculated, the obtained values are compared with the critical value of $\lambda_{\text {a }}$. If the calculated values of it do not exceed the critical ones, this indicates that there is no abnormal value for the given level of the row, otherwise, there is an ejection.

$$
\lambda_{t}=\frac{\left|y_{t}-y_{t-1}\right|}{\widehat{\sigma}_{y}}, t=2,3, \ldots, n
$$

If an abnormal value was detected, then some techniques suggest getting rid of it and continuing calculations without its value. Others recommend replacing it with averaged value. To model economic phenomena, especially such as risk, it is important to understand that there are situations that can generate the ejection. Therefore, they should be taken into account. To do this, it is proposed to use an additional fictitious variable which value will be equal to " 0 " for those levels of the row in which there is no anomaly and "1" for those where the ejection is detected.

At the third stage, the selection of relevant factors is carried out for each of the four groups that determine the risk of the business activity. This procedure can be carried out using various methods, one of which is a regression analysis, in the process of which the standardized regression equations are constructed. The standardized coefficients allow us to assess the importance of factors, to rank the regressors by the power of their influence on the regress and, to select only those that have a strong connection with the regressand. Since the risk factors of the business activity have different measurements, this approach will allow us to compare them. The equations are constructed using Formula 4:

$$
t_{y^{1}}=\beta_{1}^{1} t_{x_{1}^{1}}+\beta_{2}^{1} t_{x_{2}^{1}}+\cdots+\beta_{p}^{1} t_{x_{p}^{1}}+\varepsilon^{1}
$$

where $t_{y^{1}}-$ a standardized regressand variable, which is a level of risk of the business activity, and which is influenced by internal extensive factors; $t_{x_{1}^{1}}, t_{x_{2}^{1}}, \ldots, t_{x_{p}^{1}}$ - standardized regression variables, which are internal extensive factors (see Table 1); $\beta_{1}^{1}, \beta_{2}^{1}, \ldots, \beta_{p}^{1}$ - standardized regression coefficients obtained by applying the least squares method to equation $4 ; \varepsilon^{1}-$ a random variable.

The standardized variables are calculated as:

$$
t_{y^{1}}=\frac{y^{1}-\overline{y^{1}}}{\sigma_{y^{1}}}, t_{x_{j}^{1}}=\frac{x_{j}^{1}-\overline{x_{j}^{1}}}{\sigma_{x_{j}^{1}}}, j=\overline{1, n}
$$

The average values of standardized variables are 0 , and their average square deviations are equal to 1 . Similarly to equation 4 , we create three more equations for: 1) the risk of the business activity, which is influenced by internal intensive factors; 2 ) the risk of the business activity, which is influenced by external extensive factors; 3 ) the risk of the business activity, which is influenced by external intensive factors.

As a result of evaluating and defining the standardized coefficients of $\beta$, we find those factors that are 
P. Berzin, O. Shyshkina, O. Kuzmenko, H. Yarovenko. Innovations in the Risk Management of the Business Activity of Economic Agents

the most influential. To do this we calculate the delta coefficients $\left(\Delta_{j}\right)$ to determine the share of the impact of each factor in the total effect of all factors (Formula 6):

$$
\Delta_{j}=\frac{\beta_{j} \cdot r_{y x_{j}}}{R^{2}}
$$

where $R^{2}$ - determination coefficient; $r_{y x j}$ - coefficients of pair correlation between the regress and $j$-th regressor.

The greater the value of the delta coefficient is, so the greater the share of the impact of the factor is in the total effect. Accordingly, a decision is made to leave this factor for further study.

At the fourth stage, there is the normalization of the factors selected on the third stage based on the Minkowski approach [33, p. 70-71], which will help to obtain the integral indicators for the four groups of risk factors. This procedure will solve the problem with different measurements of the selected factors and will allow them to be aligned in the range from 0 to 1 . At the same time, the value of the integral indicator, which is approaching 1, will indicate that there is no risk, otherwise, the factors generate excessive risk.

Since the factors selected for risk modelling are stimulants and disinfectants, first it is necessary to determine the standard values of partial criteria (Formulas 7-8) [33, p. 70-71]:

$$
\begin{gathered}
x_{\max _{j}}=\max _{i} x_{i j}, j=\overline{1, k}, x \in M-\text { for stimulants } \\
x_{\min _{j}}=\min _{i} x_{i j}, j=\overline{k+1, n}, x \in U \text {-for disinfectants }
\end{gathered}
$$

where $x_{i j}$ - selected factors that influence the risk of the business activity, by the i-th type of the business activity risk, which is affected by internal intensive factors, internal extensive factors, external intensive factors and external extensive factors and by j-th factor, which exercises this influence; $M$ and $U$ - the set of criteria for stimulants and disinfectants respectively.

Then it is necessary to carry out the normalization of the values of factors (Formula 9) [33, p. 70-71]:

$$
x_{i j}^{*}=\left\{\begin{array}{c}
\frac{x_{i j}}{x_{\text {max }_{j}}}, j=\overline{1, k}, x \in M, \\
\frac{x_{\text {min }_{j}}}{x_{i j}}, j=\overline{k+1, n}, x \in U
\end{array}\right.
$$

To form an integral indicator, it is necessary to determine the weight of each factor with which it affects the general function. As such scales, standardized coefficients of multiple regression that were built at the third stage can be used. The condition for the formation of weights is $\sum_{j=1}^{n} \omega_{j}=1$, which is executed if we determine the sum of standardized coefficients. To determine the four integral indicators of the business activity risk, which are affected by internal intensive factors, internal extensive factors, external intensive factors and external extensive factors, we use the formula of the Minkowski Metric (formula 10) [33, p. 70-71]:

$$
R\left(x_{i}\right)=1-\sqrt{\sum_{j=1}^{k} \omega_{j}\left|1-\frac{x_{i j}}{x_{\max }}\right|^{2}+\sum_{j=k+1}^{n} \omega_{j}\left|1-\frac{x_{\min _{j}}}{x_{i j}}\right|^{2}}
$$


P. Berzin, O. Shyshkina, O. Kuzmenko, H. Yarovenko. Innovations in the Risk Management of the Business Activity of Economic Agents

As a result of applying to four sets of factors, we get four integral indicators that form the risk of the internal and external environment, taking into account extensive and intensive factors.

At the fifth stage, a risk model of the business activity is built taking into account four components and a quadrilateral centroid. The model was built using the GeoGebra Classical software package. Figure 1 shows a graphic model of a quadrilateral, a square whose sides are integral indicators that are obtained at the fourth stage, which form a number of factors. In this case, the square serves as a benchmark, the centroid (centre of mass) of which is at the intersection of its diagonals ("CenterOfMass"), which also coincides with the centre of the described circle. The length of the sides of the square is 1 since the risk value is from 0 to 1 . Figure 1 shows the ideal situation where the relationship between the factors that affect the risk is optimal, indicating that it is absent.

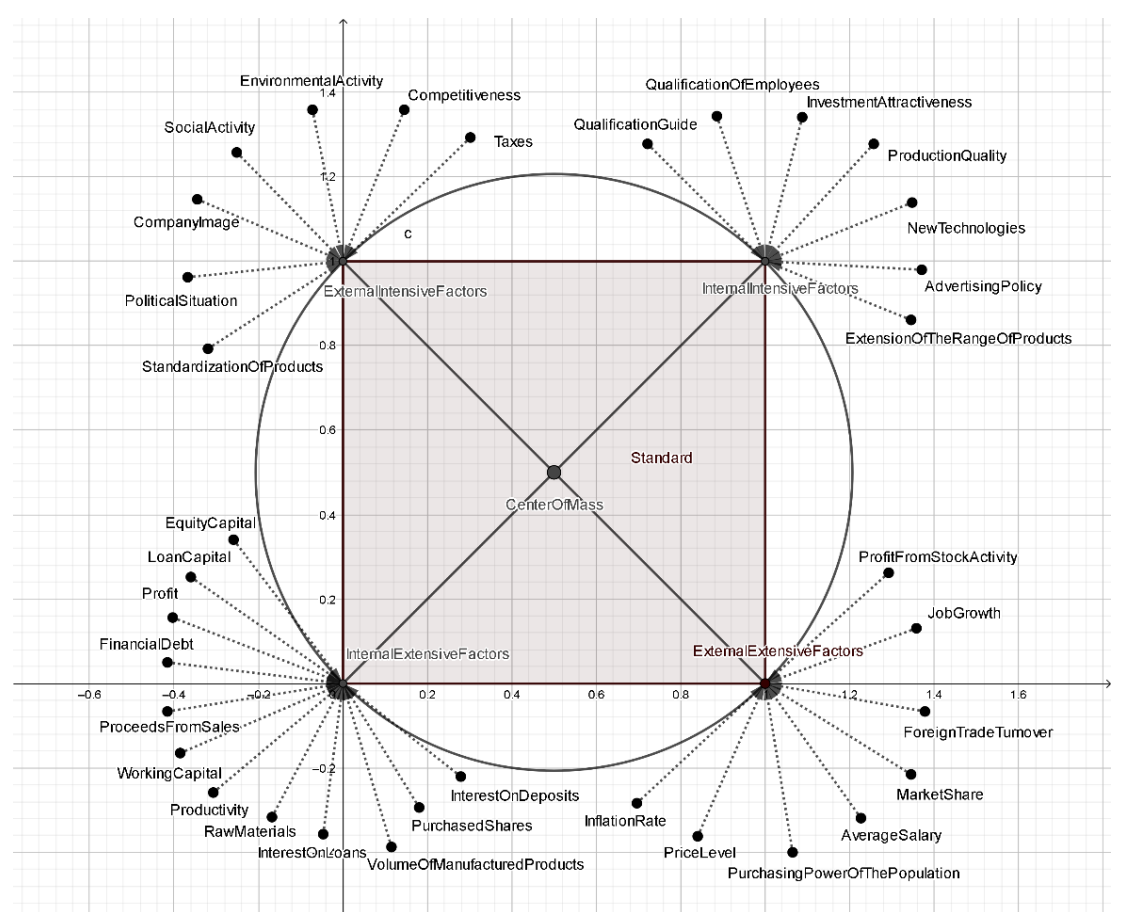

Figure 1 - Graphic standard model of the risk of the business activity of economic agents

Sources: developed by the authors on the basis of $[30,31]$

In practice, the ratio of the four groups of factors can generate different forms of quadrilaterals convex, concave and complex, with different lengths of sides and different angles. We will formulate the rules for interpreting the constructed quadrilaterals of the risk of the business activity:

1) the length of the sides of the quadrilateral must be in the range from 0 to1. The closer the value is to 1 , the lower the risk is which is generated by this group of factors. The closer the value of the side length is to 0 , the greater the risk is which is generated by this group of factors;

2) a circle can be described around the quadrilateral if the sum of its opposite angles is $180^{\circ}$. We deal with convex quadrilaterals, although there are separate cases of quadrilaterals that are self-crossed and around which a circle can be described. In other cases, if the circle cannot be described, it will refer to the excessive risk that is generated by separate groups of factors; 
P. Berzin, O. Shyshkina, O. Kuzmenko, H. Yarovenko. Innovations in the Risk Management of the Business Activity of Economic Agents

3) if it is possible to describe a circle around a quadrilateral, then its centre should be as close as possible to the centre of mass. In this case, the risk will decrease. If the centre of the circle described around the quadrilateral coincides with the centre of mass, then we deal with a square - the standard value of the absence of risk and the balance of the business activity.

The risk model is constructed as follows: on the coordinate plane, the sides of the quadrilateral are laid which are the values of the integral indicators obtained at the $4^{\text {th }}$ stage. We calculate the value of the radius of the circle, which is described around the quadrilateral by the Formula 11:

$$
R=\frac{1}{4} \sqrt{\frac{(a b+c d)(a d+b c)(a c+b d)}{(p-a)(p-b)(p-c)(p-d)}}
$$

where $a, b, c, d-$ the sides of the quadrilateral, defined as integral indicators at the $4^{\text {th }}$ stage; $p$ quadrilateral semi-perimeter, calculated as: $p=\frac{a+b+c+d}{2}$.

We determine the centre of mass of the quadrilateral, which coordinates are determined by the Formulas 12-13 [34]:

$$
\begin{aligned}
& F_{x}=\frac{1}{6 A} \sum_{i=0}^{n-1}\left(\left(x_{i}+x_{i+1}\right)\left(x_{i} y_{i+1}-x_{i+1} y_{i}\right)\right) \\
& F_{y}=\frac{1}{6 A} \sum_{i=0}^{n-1}\left(\left(y_{i}+y_{i+1}\right)\left(x_{i} y_{i+1}-x_{i+1} y_{i}\right)\right)
\end{aligned}
$$

where $F_{x}$ and $F_{y}$ - coordinates of the quadrilateral center of mass; $\left(x_{i} ; y_{i}\right),\left(x_{i+1} ; y_{i+1}\right)$ - coordinates of the vertices of the quadrilateral, where the vertex with coordinates $\left(x_{n} ; y_{n}\right)$ will coincide with the vertex with coordinates $\left(\mathrm{x}_{0} ; \mathrm{y}_{0}\right) ; \mathrm{A}$ - the square of the quadrilateral, which is determined by the Formula 14 [34]:

$$
\mathrm{A}=\frac{1}{2} \sum_{i=0}^{n-1}\left(x_{i} y_{i+1}-x_{i+1} y_{i}\right)
$$

An example of the constructed quadrilateral $A B C D$ is shown in Figure 2, where $B E$ is the radius of the circle described around the quadrilateral, $F$ is the centre of mass.

We put off on the coordinate plane the standard risk model - a square along with the circle described (Figure 2). Applying the formulas 1.12-1.13, we determine the coordinates of the centre of mass of the standard, that is, we obtain $Q(0,5 ; 0,5)$. As a result, it is clear that $F Q$ is a segment that shows the distance between the centres of mass of the actual quadrilateral and the standard one. That is, we can determine that there is a risk of the business activity that is generated by groups of factors. To minimize the risk, it is necessary that the length of this segment is close to the minimum value, that is:

$$
F Q=\sqrt{\left(x_{2}-x_{1}\right)^{2}+\left(y_{2}-y_{1}\right)^{2}}=\sqrt{\left(0,5-x_{1}\right)^{2}+\left(0,5-y_{1}\right)^{2}} \rightarrow \min
$$

From Figure 2, it can also be seen that the group factors that correspond to the CD side are those that negatively impact on the level of risk of the business activity.

If we get a quadrilateral, around which it is impossible to describe a circle, then we deal with an increased risk. If the centre of the described circle is outside the quadrilateral, this also indicates the increased risk of certain groups of factors. If it is impossible to build a quadrilateral, since three of the sides are very close to 0 , this also indicates a significant risk. These situations should be investigated in detail to identify the causes of the increased risk of the business activity. 
P. Berzin, O. Shyshkina, O. Kuzmenko, H. Yarovenko. Innovations in the Risk Management of the Business Activity of Economic Agents

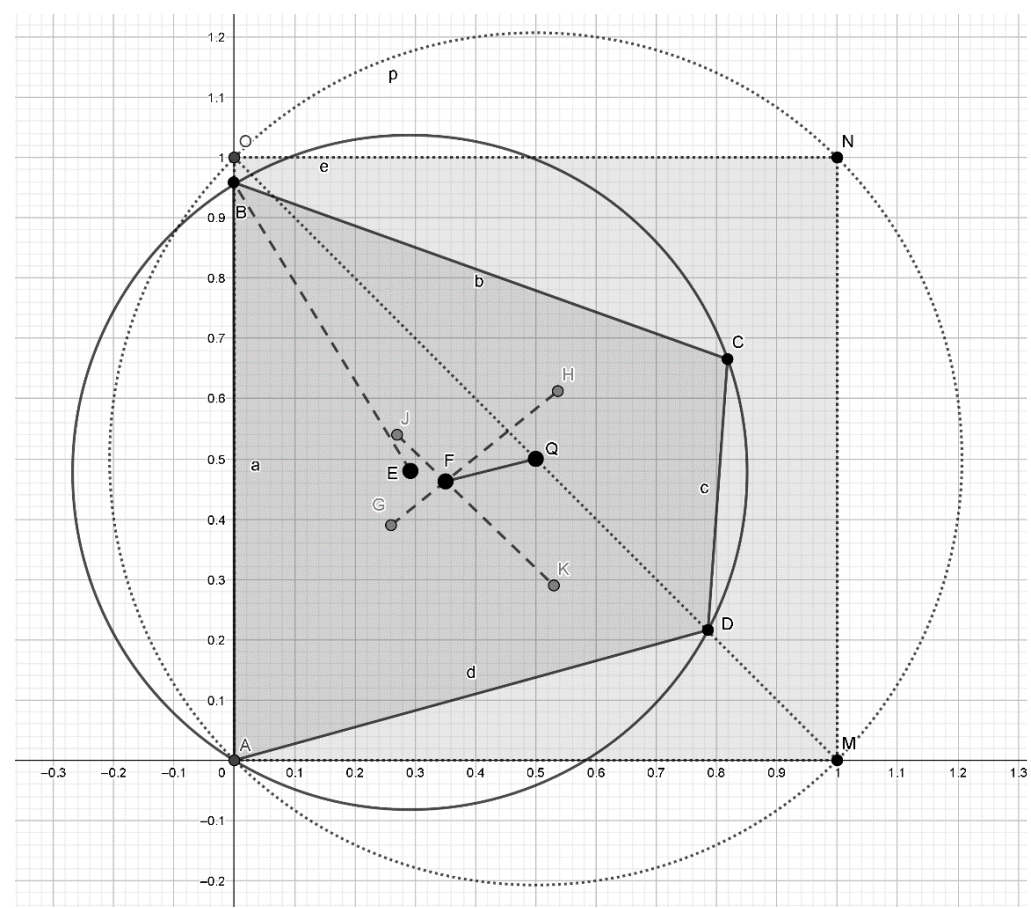

Figure 2 - An example of a graphic model of the risk of the business activity using the centre of mass of a convex quadrilateral

Sources: developed by the authors

At the sixth stage, the analysis of the results of modelling and defining the strategies are carried out. With this purpose, the scenario of probable options for the correlation of four groups of risk generating factors, which includes possible directions for improving the components of one or another group of risks, is being constructed. Thus, it has been found that group factors that correspond to the CD side (see Figure 2 ) increase the risk of the business activity. This is the group of internal intensive risk. With the help of standardized regression equations, the most important factors that form the internal intensive risk were selected. For example, the factors of managerial qualification, investment attractiveness and the level of use of new technologies were included here. An actual analysis of the current situation of the economic agent is carried out in relation to these factors. The causes of negative influence are determined. For example, the low qualification of key managers led to a number of ineffective decisions, followed by changes in the business activity to the negative side. We model new conditions in which the situation changes with regard to raising the level of competence of the management or replacing its key persons. We predict the value of factors in the light of new conditions, determine the integral risk indicator, construct the new quadrilateral. The results obtained are compared with the previous version of the constructed quadrilateral. If the distance between the centres of mass of the quadrilateral has decreased, then such a scenario option is accepted. Otherwise, another is formed. Thus, scenarios are developed for other risk groups that are in an unfavourable risk area for the economic agent. The construction of such scenarios will increase the efficiency of management decisions since it allows to gradually track the impact of changes on risk and get the predicted result.

Conclusions. Despite the large number of publications devoted to the content of the business activity, the nature of risks, methods for their identification and assessment, many aspects of the components of 
P. Berzin, O. Shyshkina, O. Kuzmenko, H. Yarovenko. Innovations in the Risk Management of the Business Activity of Economic Agents

the risk management system, which are aimed at minimizing the negative effects on economic agents, remain the subject of lengthy and sharp discussions. In order to improve the efficiency of managerial decisions, modern innovative approaches are needed, for implementation of which the economic and mathematical methods and models are used. The need to develop such an approach led to the choice of the topic of this research work.

The concept of the business activity is a complex one, which allowed to allocate the business activity in the internal and external environments, to determine stimulant and disinfectant factors, to take into account their intensive and extensive impact. As a result, the authors systematized the main risk generating factors of the business activity, taking into account the environment, nature, and sign of impact.

The authors developed the innovative approach to assessing the risks of the business activity, which is based on six main stages: the formation of four groups of key risk generating factors; the study of abnormal ejections; conducting the regression analysis to select factors by their impact on the risk; development of integral indicators of risk groups; construction of the graphics model of a quadrilateral with the definition of the centre of mass and radius of the circle described; formation of strategies for improving the effectiveness of risk management by constructing scenarios of probable options for the correlation of four groups of risk generating factors. The proposed approach will help to increase the efficiency of risk management of the business activity of economic agents but does not allow to completely neutralize the impact of risks on the performance of their functioning and development. The solution to this problem will be the subject of future study by the team of authors of this research work.

Funding. The article was executed in the framework of state budget scientific research work № 0118 U003574 "Cyber security in the fight against bank fraud: protection of financial services consumers and growth of financial and economic security of Ukraine".

\section{References}

1. Anisimova, O.M. (2013). Analysis of the business activity of the enterprise as a system evaluation of the efficiency of using own resources. Problemy ta perspektyvy rozvytku pidpryyemnytstva. no. 2, pp. 19-24. Retrieved from: http://nbuv.gov.ua/UJRN/piprp_2013_2_6

2. Harasyuk, O.A. \& Ihnatenko M.YU. (2010) Problems with the essence of the concept "business activity of the enterprise". Visnyk KTU. no. 22. - p. 63 (in Ukrainian).

3. Kashchena, N.B., Horoshans'ka O.O. \& Pol'ova T.V. (2016). Business activity of the enterprise: the essence and methods of analysis. Kh.: Vydavnytstvo Ivanchenka I.S. (in Ukrainian).

4. Zaikina, O.O. (2008). The role of indicators of business activity in the assessment of enterprise management. Kharchova promyslovist. no. 7, pp. 144-148 (in Ukrainian).

5. Kireytsev, H.H. (2002). Financial management. Kyiv: TSUL (in Ukrainian).

6. Kovalenko, L.O. \& Remnyava, L.M. (2005). Finansovyy menedzhment [Financial management]. Kyiv: Znannya

7. Kurylenko, T.P. (2009). Theoretical Aspects of Definition of Business Activity. Retrieved from www.nbuv.gov.ua/portal/Soc_Gum/Nvamu/Ekon/2009_6/6.pdf.

8. Myeshkova, N.L. (2013). Economic essence of business activity of industrial enterprise. Visnyk ekonomichnoyi nauky Ukrayiny. no 1, pp. 105-108. (in Ukrainian).

9. Mets, V.O. (1999). Economic analysis of financial results and financial condition of the enterprise: training. manual. Kyiv: KNEU (in Ukrainian).

10. Petrenko, M.I. (2010). Assessment of business activity of the enterprise. Problemy pidvyshchennya efektyvnosti infrastruktury: zb. nauk. prats. no. 26. Retrieved from http://www.nbuv.gov.ua/portal/soc_gum/ppei/2010_26/ index.html (in Ukrainian).

11. Tkachuk, H.YU. (2015). Estimation of business activity of the enterprise. Naukovyy viznyk Khersonskoho derzhavnoho universytetu. Seriya: Ekonomichni nauky. (Vols.1-4), pp. 88-90 (in Ukrainian).

12. Turylo, A.M., Zinchenko O.A. \& Vchorashnya, I. S. (2011). Definition of criteria for distribution of categories "business activity of the enterprise" and "market activity of the enterprise". Marketing and Management of Innovations, 1, pp. 82- 85.

13. Tsal-Tsalko, YU.S. (2008). Financial Analysis. Kyiv: Tsentr uchbovoyi literatury (in Ukrainian).

14. Sheremet, A.D. \& Nehashev, YE.V.(2013). Methodology of financial analysis. Moskva: NYTS Inf-ra-M (in Russian) 
P. Berzin, O. Shyshkina, O. Kuzmenko, H. Yarovenko. Innovations in the Risk Management of the Business Activity of Economic Agents

15. Yakovenko T. V. (2015). Business activity: problems of formation of a motivational complex. Visnyk Kharkivskoho natsionalnoho universytetu imeni V.N. Karazina, pp. 27 - 30. Retrieved from https://periodicals.karazin.ua/ssms/article/view/5488 (in Ukrainian).

16. Blank I.A. Fundamentals of financial management. (Vols 1-2). - Kyiv: Nyka - Tsentr: Elha, 1999. - 511s. (in Russian).

17. Vitlins'kyy, V.V. \& Velykoivanenko, H.I. (2004). Risk in Economics and Entrepreneurship. Kyiv: KNEU (in Ukrainian).

18. Hrabovoyi, P. H., Petrova, S. N., Poltavtsev, S. I., Romanova, K. H., Khrustalev, B. B. \& Yarovenko, S. M. (1994). Risks in modern business. Moskva: Alans (in Russian).

19. Hranaturov, V. M. (1999). Economic risk: essence, methods of measurement, ways of reduction. Moskva: Delo i Servis (in russian).

20. Kleyner, H.B. (1997). An enterprise in an unstable economic environment: risks, strategies, security. Moskva: OAO «Yzd - vo «Ékonomyka» (in russian).

21. Popova, A. YU. (2003). Risk management of investment activity. Kh.: Kharkivs'kyy natsional'nyy un-t im. V.N.Karazyna. (in Russian).

22. Rohov, M. A. (1996). Introduction to Financial Risk Management. Market Risk Management: Learning. allowance. Moskva: Ynfra-M (in Russian)

23. Redkhed, K., Hius, S. (1996). Upravleniye finansovymi riskami [Financial Risk Management]. M.: Infra-M, 228s. (in Russian).

24. Savchuk, V. (2014). Risk management. Basic principles and modern technologies. Kyiv: Companion Group (in Ukrainian)

25. Starostyna, A. O., \& Kravchenko, V. A. (2009). Risk Management: Theory and Practice. Kyiv: Kondor; Politekhnika (in Ukrainian).

26. Shapkyn, A.S. (2003). Economic and financial risks. Assessment, Management, Investment Portfolio: Moskva: Yzdatelskotorhovaya korporatsyya "Dolykov y K» (in russian).

27. Lobanov, A.A \& Chuhunov, A. V. (2009) Encyclopedia of Financial Management Risk. Moskva: Alpyna Biznes Buks (in Russian).

28. Shyshkina Olena (2016). Metody minimizatsiyi ta neytralizatsiyi finansovykh ryzykiv: teoretychni ta praktychni aspekty Problemy ta perspektyvy ekonomiky ta upravlinnya, no 4 (8), pp. 176-181 (in English).

29. Shyshkina, O.V (2015). Identyfikatsiya ryzykiv ta zahroz stiykoho funktsionuvannya ta rozvytku promyslovykh pidpryyemstv [Identification of risks and threats of sustainable operation and development of industrial enterprises]. Ukrayina - YES. Suchasni tekhnolohiyi, biznes ta pravo: zbirka mizhnarodnykh naukovykh prats: u 2 chastynakh. Chastyna 2. Suchasna tekhnika. Stalyy rozvytok. Innovatsiyi v sotsial'niy roboti: filosofiya, psykholohiya, sotsiolohiya. Aktualni problemy yurydychnoyi nauky ta praktyky. Chernihiv: CNUT, pp. 128-130. (in Ukrainian)

30. Kuzmenko, O.V. \& Kolotilina, O.V. (2018). Simulation of the assessment of the level of economic, social and political development of Ukraine, Italy and France in the context of optimizing their interaction. Sustainable Development of Economy, 2(39), 111-120.

31. Kuzmenko, O.V. (2014), "Practical aspects of modeling the stable political and economic situation in the country on the basis of multi-criteria optimization methods", Journal of Strategic and International Studies, 4, Volume IX,17-24. (n English)

32. Kalchenko, O.M. \& Shyshkina, O.V. (2018). Financial Analysis. Chernihiv: Vydavets Brahynets O.V. (in Ukrainian).

33. Ky'ry'chok, T.Yu. (2013) Algorithm for solving a multicriterial problem of choosing the indicator of banknote wear using the utility function. Naukovi visti NTUU «KPI». Scientific news of NTUU "KPI", 1, $68-75$ (in Ukrainian).

34. Bourke, Paul (1988) Calculating the area and centroid of a polygon. Swinburne Univ. of Technology, 7.

П. С. Берзін, д.ю.н., професор, Київський національний університет імені Тараса Шевченка (Україна);

O. B. Шишкіна, к.е.н., доцент, Чернігівський національний технологічний університет (Україна);

O. B. Кузьменко, д.е.н., доцент, Сумський державний університет (Україна);

Г. М. Яровенко, к.е.н., доцент, Сумський державний університет (Україна).

Інновації в ризик-менеджменті ділової активності економічних агентів

Стаття присвячена розробці інноваційного підходу в ризик-менеджменті ділової активності економічних агентів, який базується на застосуванні економіко-математичних методів. Підхід передбачає реалізацію наступних етапів. Запропоновано формування чотирьох груп основних ризико-формуючих факторів ділової активності у внутрішньому та зовнішньому середовищах з урахуванням факторів-стимуляторів та дестимуляторів, їх інтенсивного та екстенсивного характеру впливу. Проведено дослідження обраних факторів на аномальність (для цього фактори задаються у вигляді часових рядів, які перевіряються на аномальність за допомогою модифікованого критерія Ірвіна). Визначено процедуру відбору релевантних факторів для кожної з чотирьох груп, які визначають ризик ділової активності. Автори пропонують провести регресійний аналіз, в процесі якого будуються стандартизовані рівняння регресії для оцінки важливості чинників та їх впливу на ризик ділової активності. Розроблено інтегральні показники груп ризиків на основі метрик Мінковського. Отримане значення інтегрального показника, яке наближатиметься до 1, буде свідчити про відсутність ризику, в протилежному випадку фактори генерують надмірний ризик. Побуловано модель ризику ділової активності з урахуванням чотирьох компонентів та центроїду 
P. Berzin, O. Shyshkina, O. Kuzmenko, H. Yarovenko. Innovations in the Risk Management of the Business Activity of Economic Agents

чотирикутника. Еталонну модель побудовано із використанням програмного пакету "GeoGebra Classical". В результаті отримано квадрат, центр мас якого знаходиться у точці перетину його діагоналей, яка також співпадає з центром описаного кола. Для аналізу отриманих результатів моделювання та визначення стратегій. Побудовано сценарій ймовірних варіантів співвідношень чотирьох груп ризико-формуючих факторів, який включає можливі напрямки поліпшення складових тієі чи іншої групи ризиків. Побудова таких сценаріїв сприятиме підвищенню ефективності управлінських рішень, оскільки дозволяє поетапно відслідкувати вплив змін на ризик та отримати прогнозований результат.

Ключові слова: ділова активність, ризик ділової активності, економічний агент, управління ризиками, інноваційний підхід, графічна модель, центр мас.

Manuscript received: 29.09.2018

(C) The author(s) 2018. This article is published with open access at Sumy State University. 